\title{
レンサ球菌感染症研究会年次報告
}

\section{劇症型 $\mathrm{A}$ 群レンサ球菌感染症患者由来株における 菌体外産生物質の性状}

\author{
麻布大学環境保健学部生物有機化学講座 \\ 鈴木 潤吉原 英览少林 貞男
}

(平成 8 年 10 月 30 日受付)

(平成 8 年12月19日受理)

Key words: streptolysin O, proteinase, DNase, erythrogenic toxin, streptococcal toxic shock syndrome

要旨

劇症型 $\mathrm{A}$ 群レンサ球菌感染症患者分離株と, 咽頭炎および猩紅熱患者対照株が産生するストレプトリ ジンO (SLO), proteinase, 発赤毒素およびDNaseについて, 産生量とそれらの性状について検討し た。劇症株で対照株より平均産生量が上回ったのはSLO および DNase であり, 病原性を有する SLOで は劇症群10例中 2 例, 対照群15例中 1 例が高值を示した。これまで, 起因菌の産生する外毒素により ショック状態が誘発されることが報告されているので，劇症株では発赤毒素の高活性を期待したが，対 照株と差が見られなかった. SLO は pI 分析によると acidic type SLOであり，分子量もこれまでの報 告と同様に64,000を示した.また, proteinase の pI および分子量についてもザイモグラムを用いて対照 株と比較したが, 両者で差が認められなかった。いくつかの産生物質の示す活性の総和が病因になると 考えられるが，検討した 4 種の菌体外産生物質では streptococcal toxic shock syndrome に共通する傾 向が認められないことより，これら複数の因子による病原性発現の多様性が強く示唆された.

\section{序 文}

近年, わが国ではレンサ球菌による streptococcal toxic shock syndrome (STSS) が相次いで 報告12)されている. 本症は起因菌の発赤毒素によ りショック状態が誘発されることが明らかにされ ているが, 細胞障害, 組織壊死および血圧降下等 への関与については不明な点が多い.われわれは 起因菌の病原性発現機構を知るための第一段階と して, STSS 患者より分離した劇症株について菌 体側からの検討を試みた.S. pyogenes は生育に伴 い多くの菌体外生理活性物質を産生することが知 られているが，スーパー抗原活性を有する発赤毒 素3), 強い溶血活性と共に心筋壊死作用, 白血球障

別刷請求先：(テ229）相模原市㴊野辺 1-17-71 麻布大学環境保健学部生物有機化学講座 鈴木 潤
害作用 ${ }^{4)}$ を有するストレプトリジンO (SLO)，ま たカリクレインーキニン系を活性化すると共に組 織破壊作用を持つ proteinase ${ }^{5)}$ ，および病原菌の 組織侵入性を促進させるDNase ${ }^{6}$ の 4 種につい て, 劇症株と咽頭炎および猩紅熱患者由来の対照 株との比較検討を行なった。

\section{材料と方法}

1. 使用菌株および培養

劇症型 $\mathrm{A}$ 群レンサ球菌感染症患者分離株（10 株）および対照として咽頭炎（7株）および猩紅 熱患者由来株（8株）を実験に供した。なお，劇 症株は旭中央病院清水可方博士，対照株は東邦大 学医療短期大学村井貞子博士より分与して戴い た。培養は富養化 Todd-Hewitt 限外濾過培地 （3\%グルコース，1\%酵母抽出液添加）で $37^{\circ} \mathrm{C} 16$ 18時間行なった。培養上清は無調製で溶 
血, proteinase, 発赤および DNase の各活性の測 定に用いた。

\section{2. $\mathrm{pI}$ 測定および分子量測定}

$\mathrm{pI}$ 測定はアガロースゲル等電点電気泳動, 分子 量測定は TLGアパラータス (Pharmacia-LKB) を用いた Sephadex G-200 superfine 薄層ゲル濾 過法により行なった。なお, proteinase の pI 分析 および分子量測定では等電点電気泳動後あるいは 薄層ゲル濾過展開後のゲルプレートに, カゼイン 含有ゲルプレートを直接重層させ，酵素活性を指 標とした $\mathrm{pI}$ おび分子量を求めた。

\section{3. 溶血阻害実験}

溶血力価測定法7は既報に従ったが，その際に

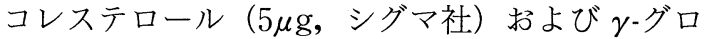
ブリン $(100 \mu \mathrm{g}$ ，ミドリ十字社）を加えて活性の阻 害能を測定した。

\section{DNase の測定}

DNase メチルグリーン法吕を用いて DNase 活 性の測定を行なった。すなわち，DNA-メチルグ リーン複合体を含むアガロースゲル中での DNA の分解に伴う脱色部の直径より活性を求めた。

5. Proteinase 活性の測定

カゼインを基質とする Grushoff' ${ }^{8}$ 法に従った が，還元剤としては2-メルカプトエタノール（2ME）を用いた。

6. 発赤力価の測定

Table 1 Comparison of products profiles among streptococci isolates from patients with and without clinical signs of STSS

\begin{tabular}{|c|c|c|c|c|c|c|c|c|}
\hline \multirow{2}{*}{ Strain } & & \multicolumn{2}{|c|}{ Type } & \multicolumn{2}{|c|}{$\mathrm{SLO}\left(\mathrm{HD}_{50} / \mathrm{ml}\right)$} & \multirow{2}{*}{$\begin{array}{l}\text { Proteinase } \\
(\mathrm{U} / \mathrm{ml})\end{array}$} & \multirow{2}{*}{$\begin{array}{l}\text { Erythrogenic } \\
\text { toxin (STD/ml) }\end{array}$} & \multirow{2}{*}{$\begin{array}{l}\text { DNase } \\
(\mathrm{U} / \mathrm{ml})\end{array}$} \\
\hline & & M & $\mathrm{T}$ & $+2 \mathrm{ME}$ & $-2 \mathrm{ME}$ & & & \\
\hline \multirow{12}{*}{$\begin{array}{l}\text { with STSS } \\
\text { Asahi }\end{array}$} & 1 & 3 & 3 & 326.0 & 104 & 0.7 & $9.4 \times 10^{4}$ & 162 \\
\hline & 2 & 4 & 4 & 1.2 & 0 & 1.0 & 8.3 & 175 \\
\hline & 3 & 3 & 3 & 146.0 & 71.6 & 7.0 & 7.4 & 183 \\
\hline & 4 & 22 & 22 & 1.5 & 0 & 1.4 & 0.85 & 23 \\
\hline & 5 & - & 3 & 1.2 & 0 & 2.4 & 0.52 & 115 \\
\hline & 6 & 4 & 4 & 1.2 & 0 & 5.6 & 18.0 & 175 \\
\hline & 7 & 3 & 3 & 1.2 & 0 & 7.0 & 10.0 & 175 \\
\hline & 8 & 3 & 3 & 1.3 & 0 & 1.0 & 12.0 & 250 \\
\hline & 9 & 3 & 3 & 1.2 & 0 & 4.0 & 13.0 & 205 \\
\hline & 10 & - & 1 & 1.2 & 0 & 4.6 & 0 & 168 \\
\hline & $\mathrm{Av}$ & & & 48.2 & 17.6 & 3.47 & $7.90 \times 10^{4}$ & 163 \\
\hline & $\mathrm{SD}$ & & & 107.7 & 35.9 & 2.50 & 5.95 & 59.7 \\
\hline \multirow{17}{*}{$\begin{array}{l}\text { without } \\
\text { STSS }\end{array}$} & 1 & 3 & 3 & 1.2 & 0 & 8.2 & $6.4 \times 10^{4}$ & 182 \\
\hline & 2 & 3 & 3 & 1.2 & 0 & 9.4 & 4.3 & 147 \\
\hline & 3 & 3 & 3 & 1.2 & 0 & 4.0 & 16.0 & 190 \\
\hline & 4 & 3 & 3 & 1.2 & 0 & 5.8 & 14.0 & 190 \\
\hline & 5 & 11 & 11 & 1.2 & 0 & 9.6 & 8.3 & 123 \\
\hline & 6 & 1 & 1 & 1.2 & 0 & 12.0 & 2.8 & 168 \\
\hline & 7 & 22 & 22 & 1.2 & 0 & 8.0 & 5.1 & 168 \\
\hline & 8 & 22 & 22 & 1.2 & 0 & 6.2 & 12.0 & 134 \\
\hline & 9 & 4 & 4 & 58.0 & 16.0 & 4.6 & 19.0 & 150 \\
\hline & 10 & 3 & 3 & 1.2 & 0 & 5.2 & 4.1 & 140 \\
\hline & 11 & 3 & 3 & 1.2 & 0 & 6.4 & 5.0 & 147 \\
\hline & 12 & 3 & 3 & 1.7 & 0 & 12.4 & 3.7 & 107 \\
\hline & 13 & 4 & 4 & 1.2 & 0 & 6.4 & 16.0 & 205 \\
\hline & 14 & 3 & 3 & 1.2 & 0 & 8.0 & 19.0 & 150 \\
\hline & 15 & 3 & 3 & 1.2 & 0 & 6.4 & 6.1 & 123 \\
\hline & $\mathrm{Av}$ & & & 5.02 & 1.1 & 7.5 & $9.5 \times 10^{4}$ & 155 \\
\hline & $\mathrm{SD}$ & & & 14.2 & 4.0 & 2.5 & 5.91 & 28.3 \\
\hline
\end{tabular}


ウサギ背部の皮内に, 滅菌生理食塩水で $10^{-5}$ 〜 $10^{-7}$ に希釈した粗毒素を $0.1 \mathrm{ml}$ づつ接種し， 18～20時間後に発赤の長径と短径を測定して，そ の平均值を発赤径とした. 発赤力価は $16 \mathrm{~mm}$ の発 赤径が得られる毒素量を1STD とした。

\section{成 績}

\section{1. 菌体外産生物質の産生量}

劇症患者分離株，対照とした咽頭炎ならびに猩 紅熱患者分離株について SLO, proteinase, DNase 抢よび発赤瑇素の産生量の成績を表に示 した (Table 1)。発赤毒素とDNase は Table 1 中のSTSS 100発赤毒素量を除いた劇症株，およ び対照株の全ての分離株で産生が認められ，劇症 および対照株間で産生量の平均值に差は認められ なかった。しかし, DNAメチルグリーン法による DNaseの定量を劇症株および対照株について行 なうと，平均值で劇症株の方がやや高い傾向を示 すものの, 有意の差ではなかった。しかし, DNase 活性量の分散の程度は，劇症株の方が大きい傾向
を示した (Table 1). また, proteinase も劇症株 および対照株の全ての株で産生したが，劇症株の 産生量は対照株よりも明らかに低く，10株中 5 株 に抢いては kunitz 法で 1 単位以下であった。一 方，血液寒天培地上では全ての分離株で溶血環が 認められたが，液体培養では劇症株は 10 株中 2 株 (20\%)，対照株では15株中 1 株（6.7\%）にのみ hemolysinの高産生が認められた。また, 産生が認 められた分離株間では劇症株の方が hemolysin の産生量が多かった。

\section{Hemolysin の性状}

劇症株および対照株において，非還元状態でも 活性を示す例が認められたので，劇症株 1,3 に ついて, pI 分析および溶血阻害実験を行なった (Fig. 1, 2).pI 分析の結果ではいずれの劇症株で も pI 6.0を中心とする活性を示し，さらにコレス テロールおよび $\gamma$-グロブリンにより溶血が阻害 される。阻害態度の成績は劇症株 3 について示し た。ここでは阻害効果を 0 〜 100\%溶血を示す阻害

Fig. 1 Determination of $\mathrm{pI}$ value of hemolysin from group A streotococci with STSS and the oxygen susceptibility of its hemolytic activity. Hemolysin of group A streptococci was applied to agarose gel containing $2 \%$ Ampholine and focused for $2 \mathrm{~h}$. Hemolytic avtivity was detected by overlaying agarose plates containing erythrocytes with or without 2 -ME. The clear band on the overlaid plate indicates hemolysis. Both lanes were loaded with $10 \mu 1$ and $20 \mu 1$, respectively.

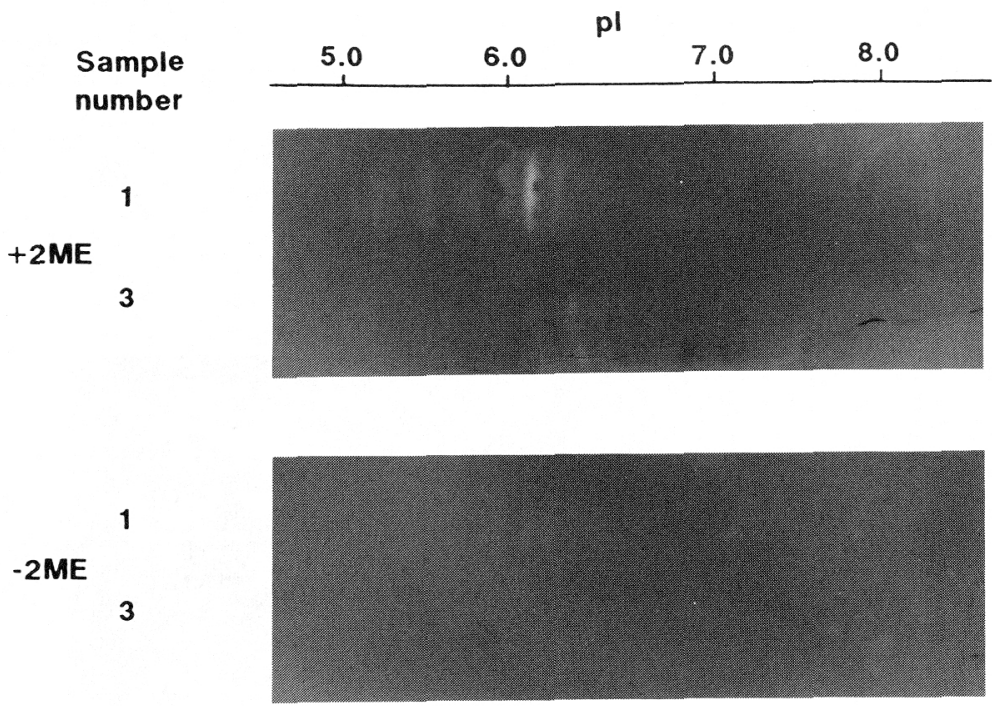


Fig. 2 Inhibition of hemolytic activity of SLO produced STSS 3 strain with cholesterol and $\gamma$-globulin. Symbol were showed $\gamma$-globulin and $(\bigcirc)$ cholesterol, respectively.

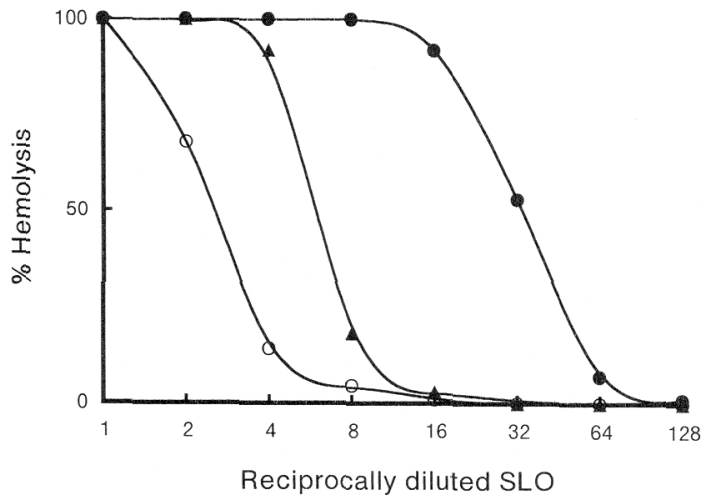

物質濃度での成績を示したが，阻害剤を高濃度に すれば溶血は完全に阻止される。また，Fig. 1 に 示した非還元状態での活性は，酸化されなかった 活性化 SLO によるものと考元られる。また，劇症 株 1 の示す分子量は既報の64,000を示すSLOの 分子量より，やや低值を示したが，劇症株 3 はほ ぼ同程度の成績であった(Fig. 3)。Hemolysin は $\mathrm{pI}$ および分子量，加えて溶血阻害態度等より， acidic type の SLOであることを確認した。

3 . proteinase の性状

pI 分析は高活性を示す劇症株 4 株, 対照株 5 株 について検討を行なったが，いずれも $\mathrm{pH}$ 8.5 8.95のアルカリ領域に 2 本の $\mathrm{pI}$ 成分が示さ れ，両株間での差は認められなかった。また，分 子量も17,000 と両株間で差は認められなかった (Table 2).

\section{考察}

劇症型 $\mathrm{A}$ 群レンサ球菌感染症に見られる軟部 組織壊死掞よびショック状態より，発赤および proteinase 活性は高值であることが期待された が，実際には対照株に比し，両活性とも平均值の 比較では下回った。一方, SLO 産生量は劇症群10 例中 2 例，対照群15例中 1 例が高值を示した。

次に SLO および proteinase の物理化学性状を 劇症株および対照株で比較すると両者で差は見ら れなかった。高産生量を示したSLO では劇症株 の 1,3 とも pI 6.0 主要成分とする acidic type であり，分子量は劇症株 10 分子量㴖か僅か低い ものの，3 ではSLO と同様の值を示した。加え て，コレステロールおよび $\gamma$-グロブリンに対する 阻害態度も対照株のSLO と同様であった。従っ

Fig. 3 Determination of the molecular weight of streptolysin by thin-layer gel filtration in the present of 2-ME. Hemolytic activity was detected as shown in Fig. 1. Lane 1 (SLO \& SLS), lanes 2, 3 (STSS 3), lanes 4, 5 (STSS 1), lane 6 (SLS). Thin-layer plate; $20 \times 20 \mathrm{~cm}$. Gel: Sephadex G-200 superfine. Layer thickness: $0.6 \mathrm{~mm}$. Time: $6.5 \mathrm{~h}$. Angle: $20^{\circ}$. The migration distance for blue dextran was $9 \mathrm{~cm}$.
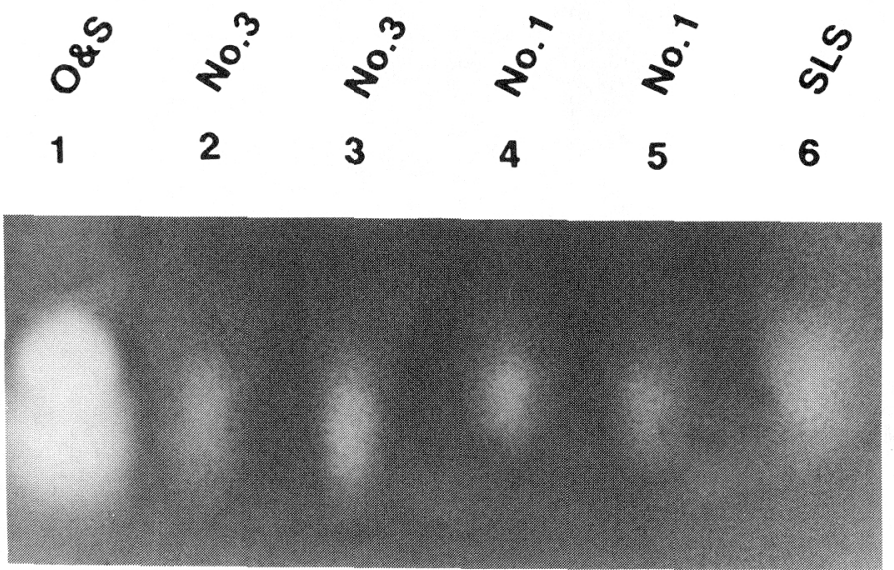
Table 2 Comparison of $\mathrm{pI}$ and MW of proteinase produced S. pyogenes isolates from patients with and without clinical signs of STSS

\begin{tabular}{lcccc}
\hline \multicolumn{1}{c}{ Strain No. } & \multicolumn{2}{c}{ Isoelectric point } & Molecular weight \\
\hline With STSS & 6 & $\underline{8.75}$ & $\underline{8.90}$ & 17,000 \\
(Asahi) & 7 & 8.70 & $\underline{8.90}$ & 17,000 \\
& 9 & 8.75 & $\underline{8.95}$ & 17,000 \\
& 10 & 8.75 & $\underline{8.93}$ & 17,000 \\
& AV & 8.74 & 0.029 & 17,000 \\
& SD & 0.025 & $\underline{8.75}$ & 0 \\
\hline Without STSS & 2 & $\underline{8.50}$ & $\underline{8.85}$ & 17,000 \\
& 6 & 8.70 & $\underline{8.75}$ & 17,000 \\
& 7 & 8.50 & $\underline{8.85}$ & $\mathrm{ND}$ \\
& 8 & 8.65 & $\underline{8.85}$ & $\mathrm{ND}$ \\
& 12 & 8.65 & $\mathbf{8 . 8 1}$ & $\mathrm{ND}$ \\
& Av & 8.61 & 0.055 & 17,000 \\
& SD & 0.102 & & 0 \\
\hline
\end{tabular}

; Major pl value ND; Not detected

て，劇症株の産生するSLO は質的にはこれまで 知られているSLO と同一であり，量的な問題が 病態に影響を与えたと考えられる。

また, hemolysinの産生は血液寒天培地では全 ての分離株で見られたのに対し, 液体培地中で高 溶血活性が認められたのは僅かであった。この理 由は proteinaseの産生によって, SLOがタンパ ク分解を受けて失活したものと思われる. 小林等 は液体培養過程のおける proteinase 産生と SLO 価との関係9)ならびに proteinase 産生能と $\mathrm{M}$ 抗 原量およびSLO 価の関係 ${ }^{10)}$ を報告しているが, こ こでも proteinase による影響が溶血活性低下に 関与していると思われる。従って, proteinaseの 産生する前段階で培養を終了すれば, 毒素量およ び検出頻度は大きく上昇するものと考えられる。

SLOの作用上の特徵は心臓に対する著しい毒 性であるが11), 拍動する培養心筋細胞に SLO を働 かせると拍動は停止し, 数分以内に膜から空胞状 の突起が生じる. また, ウサギやマウスにSLOを 接種すると強直性の痤攣がおこるが, 脳波は変化 せず血圧低下, 呼吸停止, 排尿, 下痢が起こり,

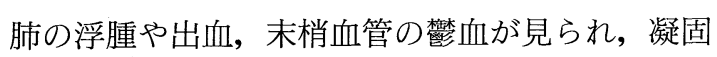
因子の変化により, 心室や大静脈の大量の血栓を 生じ易いことが報告されている。これらの特徵と 本症例との関連性は大変興味深い.また, SLOの 組織障害性はA 群レンサ球菌の発熱毒素や proteinase により増強されることも報告されて

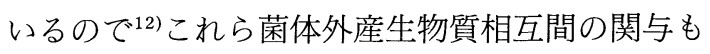
重要と推察される. 加えて, SLO の強い溶血作用 は産生する毒素量によっても異なるが, 容易に赤 血球膜を崩壊させ溶血させる. 劇症株 1 および 3 の患者からの採血時には, いずれも強溶血が見ら れたことを考慮すると, 生体内 ASLO の毒素中和 反応において過剩の SLO が病態に影響を与えた と推察される.

検討した菌体外産生物質は SLO, proteinase, 発赤毒素および DNaseの 4 種であるが, 対照株 より産生量の平均において上回ったのはSLO お よびDNaseであった.しかし, 病原性を有する SLO の高産生量が示されたのは劇症群で10例中 2 株であった。いくつかの産生物質の示す総和が 病因になることが考えられるが, 劇症株に共通す る産生物の傾向が認められないことより,これら 複数の因子による病原性発現の多様性が強く示唆 された。

謝辞 稿を終えるにあたり, 菌株の分与を戴いた旭中央 病院の清水可方博士ならびに東邦大学医療短期大学村井貞 子博士に深謝致します。

\section{文 献}

1）清水可方, 大山晃弘, 笠間和典: A 群溶連菌によ る toxic shock syndorome $の 1$ 例. 感染症誌 $1993 ; 67: 236-239$.

2）清水可方, 大江健二, 中田博一, 他：CPC 記録劇 
症型レンサ球菌感染症の臨床病理的検討. 旭中央 医報 $1994 ; 16: 476-501$.

3）志関雅幸，戸塚恭一，内山竹彦：A 群レンサ球菌 感染症とスーパー抗原. 臨床と微生物 $1996 ; 23$ : 59-64.

4) Tanigawa T, Suzuki J, Ueta T, Katsumoto $T$, Tanaka $Y$ : Different sensitivity to streptolysin-O of cells in macrophage lineage. Microbiol Immunol 1996; $40: 81-84$.

5）前田 浩：微生物プロテアーゼの病原性に関する 研究. 細菌学誌 $1995 ; 50$ : 921-936.

6) Ferreira BP, Benchetrit LC, Castro ACDDE, Batista TGFM, Barrucand L: Extracelluar deoxyribonucleases of streptococci : A comparison of their occurrence and levels of production among beta-hemolytic strains of various serological groups. Zbl Bakt 1992 ; 277 : 493503.

7) Suzuki J, Kobayashi S, Kagaya K, Fukazawa $\mathrm{Y}$ : Heterogeneity of hemolytic efficiency and isoelectric point streptolysin O. Infect Immun
$1998 ; 56: 2724-2478$.

8) Grushoff PS, Shany S, Bernheimer AW : Purification and properties of streptococcal nicotinamide adenine dinucleotide glycohydrase. J Bacteriol 1975 ; 122 : 599-605.

9）小林貞男, 浜田暁子 : 猩紅熱患者由来 A 群溶連菌 の蛋白質分解酵素産生と $\mathrm{M}$ 抗原量, ストレプトリ ジンＯ洒および菌型について。感染症誌 1982 ; $56: 20-25$.

10）小林貞男：溶血連鎖球菌発赤毒素一精製およびそ の物理化学的性状一. 栄研学術叢書13集, 1980 ； 163-171.

11) Halbert SP: Streptolysis O. In : Montie TC, Kadis S, Ajl SJ, eds. Microbial toxins, Vol. 3. Academic Press Inc New York, 1970; 69-36.

12) Talkington DF, Schwartz B, Black CM et al.: Association of phenotypic and genotypic characteristics of invasive Streptococcus pyogenes isolates with clinical components of streptococcal toxic shock syndrome. Infect Immun 1993 ; 61 : 3369-3374.

\section{Properties of Extracellular Products Produced by Group A Streptococci} Isolated from Patient with Streptococcal Toxic Shock Syndrome

\section{Jun SUZUKI, Eiji YOSHIHARA \& Sadao KOBAYASHI}

Department of Bioorganic Chemistry, College of Environmental Health Azabu University

Extracellular products of group A streptococci isolated from patients with streptococcal toxic shock syndrome (STSS) examined. The outline of discussion of the 4 products are as follows; Products were streptolysin O (SLO), proteinase, erythrogenic toxin and DNase. SLO showed a large amount of products more than proteinase, erythrogenic toxin and DNase. It should not be concluded that there is a large amount of SLO in the isolated strains from patients with STSS. SLO produced by group A streptococci isolated from the patient with STSS has an isoelectric point (pI) of 6.0 and a molecular weight of 64,000 and shows a hemolytic activiy in the presence of 2 mercaptoethanol (2-ME). Furthermore, the hemolytic activities of all components were inhibited by $\gamma$-globulin and cholesterol. These results indicated that all component with hemolytic activity are SLO. These data suggest that STSS does not make up a single syndrome but, rather, that the multiple STSS clinical criteria probably reflects a different characteristic of individual $S$. pyogenes isolates. 